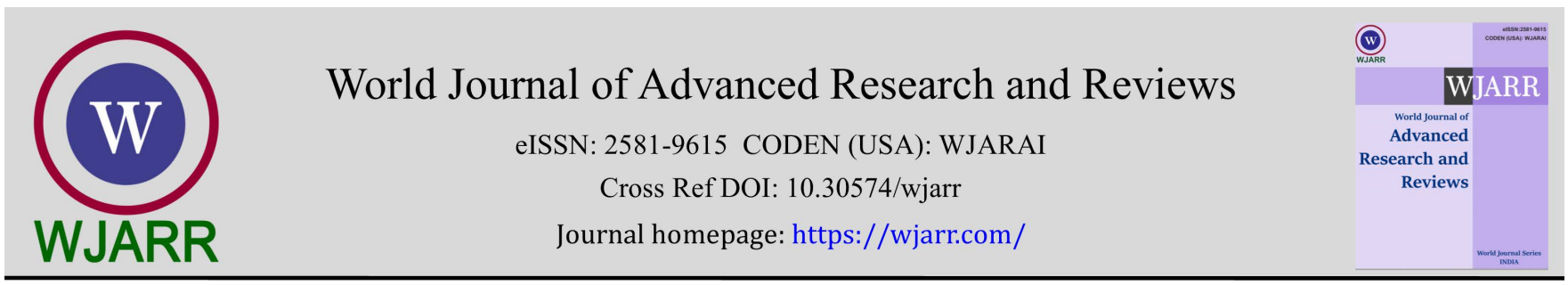

(RESEARCH ARTiClE)

Check for updates

\title{
Quality of medical prescriptions from Mwangeji Hospital and Gécamines Kolwezi Staff Hospital in Kolwezi, Lualaba province, DR Congo
}

\author{
Aaron Mutomb-a-Kaj ${ }^{1}$, Cedrick Mutombo Shakalenga ${ }^{2 *}$, Kiza Miruho Ndahetwa ${ }^{2}$ and Salvius Bakari Amuri ${ }^{2}$ \\ ${ }^{1}$ Institut Supérieur des Techniques Médicales de Kolwezi, Avenue Norbert Mbangu; Quartier Golf Plateau, Ville de \\ Kolwezi, RD Congo. \\ 2 Laboratory of Pharmacognosy, Department of Pharmacology, Faculty of Pharmaceutical Sciences, University of \\ Lubumbashi, B.P. 1825 Lubumbashi, DR Congo.
}

World Journal of Advanced Research and Reviews, 2021, 09(03), 008-013

Publication history: Received on 16 February 2021; revised on 26 February 2021; accepted on 01 March 2021

Article DOI: https://doi.org/10.30574/wjarr.2021.9.3.0064

\begin{abstract}
The medical prescription is a very important tool of communication between the physician, the patient and the pharmacist. Ambiguities and omissions of data on prescription can cause errors in drug delivery and administration and so far, endanger patients. This study was undertaken to assess the quality of medical prescription delivered in Mwangeji General Hospital (HGR Mwangeji) and Gécamines Kolwezi staff hospital (HPK-Gécamines), two health facilities in the town of Kolwezi. Medical prescriptions were collected between October 2017 and March 2018, in the pharmacy services of these two hospitals. The quality was assessed based on the presence or not of mandatory administrative and pharmacotherapeutic information. The results revealed very alarming rates of omission of legal and mandatory mentions concerning: (i) the identity of patients, their weight $92.3 \%$, their sex $54.9 \%$ and their age $53.9 \%$; (ii) the identity of prescribers, the date of issue of the document $97.8 \%$, the signature $93.4 \%$ and the name $82.1 \%$; (iii) pharmacotherapeutic data, duration of treatment $95.9 \%$ and route of administration 93,7\%. Antibiotics were the most prescribed drugs in the two hospitals; 26,6\% at HPK Gécamines and 23 at HGR Mwangeji. The quality of medical prescriptions at Mwangeji and HPK Gécamines hospitals, could lead to wrong or inadequate medical interventions with a negative impact on the quality of care administered to patients.
\end{abstract}

Keywords: DR Congo; Lualaba; Province; Medical Prescription; Patient security; Therapeutic failure

\section{Introduction}

The quality of drug care provided to patients is largely dependent on the quality of the medical prescription [1]. Unfortunately, prescribers attach in general, little importance to the quality of the drafting of their medical prescriptions, while these are supposed to be the basis of the good medication of their patients [2]. The medical prescription is an act sufficiently legislated given its importance and must hence be written accurately, completely and legibly [3]. However, despite the existence of regulations, medical prescription remains a real problem in healthcare establishments, due to a significant number of breaches of legislation [4]. Several studies carried out in this field have shown that the main editorial anomalies relate to, the absence of mandatory identifiers concerning the patient and the prescriber [5-7]. The analysis of data publishing to Nigeria, relating to the content of the medical prescription shows that $95 \%$ of medical prescriptions meet all necessary characteristics for a good drug prescription [6]. To Brazil, Leão et al. [5] shows that $25 \%$ of analyzed ordonnances are completely illegible, $61 \%$ contained drug interactions and only 14 $\%$ was good quality of drafting. In order to assess the situation of medical prescription in our environment, this study was undertaken to analyze the quality of medical prescriptions presented for execution to internal Pharmacy services

\footnotetext{
${ }^{*}$ Corresponding author: Cedrick Mutombo Shakalenga

Laboratory of Pharmacognosy, Department of Pharmacology, Faculty of Pharmaceutical Sciences, University of Lubumbashi, B.P. 1825 Lubumbashi, DR Congo.
}

Copyright (C) 2021 Author(s) retain the copyright of this article. This article is published under the terms of the Creative Commons Attribution Liscense 4.0. 
of HGR-Mwangeji and HPK-Gécamines hospitals. These two hospitals were chosen based on their importance in terms of capacity reception and prioritization of healthcare facilities according to the Democratic Republic of Congo healthcare system where they are classified at the secondary level.

\section{Material and methods}

\subsection{Study design and period}

A prospective study has been conducted between October 2017 and March 2018 in the city of Kolwezi, Lualaba Province, DR Congo. Two hospitals namely HPK-Gécamines and HGR-Mwangeji were involved in this study. The study consisted in analyzing medical prescriptions issued to the patients who consulted one of two health facilities. Only prescriptions that were served and kept in the pharmacy service of HPK-Gécamines and HGR-Mwangeji, were the subject of this analysis. These prescriptions concerned both hospitalized and non-hospitalized patients.

\subsection{Data collection}

Two kind of data were collected; the first concerns administrative data, including the patient's identity (name, age, sex and weight) and details on the prescriber (name, qualification or specialty, professional serial number and signature), as well as the date. The second kind of data includes pharmacological details related to prescribed drugs (pharmaceutical form, dosage, administration route, etc.).

\subsection{Data processing and ethical consideration}

Descriptive statistic was used to quantify frequency of modalities of qualitative variables and present them in the frequency tables. The data on the identities of patients and prescribers have been encoded according to the principle of anonymity set out in the Declaration of Helsinki and the general European regulation on the protection of personal data $[8,9]$.

\section{Results}

\subsection{Regulatory data}

A total of 4,759 medical prescriptions were collected including 3006 from HPK-Gécamines and 1753 from HGRMwangeji. The identification of patients was well observed on prescriptions from HGR-Mwangeji, where following items were mostly mentioned: name (99.4\%), sex (75.2\%) and age (90.8\%); compared to prescriptions from HPK- Gécamines where only the name was mentioned in almost all (99.9\%) of the prescriptions analyzed. Globally, patient's address was not mentioned on any prescription. Prescribers were identified in most medical prescriptions from the two hospitals. However, professional serial numbers were very weakly mentioned; $1.9 \%(n=1753)$ and $2.9 \%(n=3006)$, respectively on prescriptions from HGR-Mwangeji and HP-Gécamines. No prescriber qualification was given for all prescription.

Table 1 Frequency of identity on medical prescriptions from HGR-Mwangeji and HPK-Gécamines for both prescribers and patients.

\begin{tabular}{|l|l|l|}
\hline Expected item & $\begin{array}{l}\text { Relative frequency at HGR } \\
\text { Mwangeji (n= 1753) }\end{array}$ & $\begin{array}{l}\text { Relative frequency at HPK- } \\
\text { Gécamines (n=3006) }\end{array}$ \\
\hline Name & $99.4 \%$ & $99.9 \%$ \\
\hline Gender & $75.2 \%$ & $27.5 \%$ \\
\hline Age & $90.8 \%$ & $20.1 \%$ \\
\hline Weight & $7.9 \%$ & $7.7 \%$ \\
\hline Name & $81.9 \%$ & $82.4 \%$ \\
\hline Order number & $1.9 \%$ & $2.9 \%$ \\
\hline Signature & $85.6 \%$ & $98.0 \%$ \\
\hline Prescription date & $96.4 \%$ & $98.7 \%$ \\
\hline Prescriber qualification & $0.0 \%$ & $0.0 \%$ \\
\hline
\end{tabular}




\subsection{Pharmacotherapeutic data}

Pharmacotherapeutic data show that more than $70 \%$ of prescriptions from HGR-Mwangeji indicated the pharmaceutical form, the drug dosage and the rhythm of medication administration. The Administration route and the duration of treatment were only indicated in $6.6 \%$ and $1.2 \%$ respectively. In the prescriptions of the HPK-Gécamines, only the galenic form was indicated in more than $70 \%$ of the prescriptions. In addition, the duration of treatment was more indicated on prescriptions from HPK-Gécamines than, on those from HGR-Mwangeji.

Table 1 Frequency of pharmacotherapeutic data, on the prescriptions from HGR-Mwangeji and HPK-Gécamines in Kolwezi.

\begin{tabular}{|l|l|l|}
\hline Expected item & $\begin{array}{l}\text { Relative frequency at HGR- } \\
\text { Mwangeji (n= 1753) }\end{array}$ & $\begin{array}{l}\text { Relative frequency at HPK- } \\
\text { Gécamines (n= 3006) }\end{array}$ \\
\hline Pharmaceutical form & $76.3 \%$ & $74.5 \%$ \\
\hline Route of administration & $6.6 \%$ & $6.3 \%$ \\
\hline Dosage & $71.5 \%$ & $48.0 \%$ \\
\hline Instructions for use & $71.1 \%$ & $58.1 \%$ \\
\hline Duration of treatment & $1.2 \%$ & $5.9 \%$ \\
\hline
\end{tabular}

\subsection{Prescript pharmacological families}

When interested in the prescription frequency of drugs according to their pharmacological families, the results of HGRMwangeji show in descending order that $(\mathrm{n}=1753)$ : antibiotics $23.5 \%$, antimalarial drugs $13 \%$, vitamins $9,6 \%$ and nonsteroidal Anti-inflammatory drugs (NSAIDs) 9.4\%, were the most prescribed. Antidiabetics (0.9\%) and psychotropic drugs $(0.7 \%)$ were less prescribed $(n=1753)$. On the other hand, medical prescriptions from HPK-Gécamines $(n=$ 3006); antibiotics 26,6\%, NSAIDs 17\%, antimalarial drugs 9,7\% and antiparasitic 8,8\% ( $\mathrm{n}=3006)$ were the most prescribed. As a result, the prescriptions of the two hospitals mainly took antibiotics, antimalarials, and NSAIDs. Our results show that in the prescriptions of the two hospitals, most of the drugs were prescribed in their generic forms $62.7 \%(n=4759)$ and the drugs were named in their international nonproprietary name (INN); while the rest (37.3\%) were prescribed in branded form.

Table 3 Frequency of pharmacological family's prescript at HGR-Mwangeji and HPK-Gécamines.

\begin{tabular}{|l|l|l|l|l|}
\hline \multirow{2}{*}{$\begin{array}{l}\text { Pharmacological } \\
\text { families }\end{array}$} & \multicolumn{2}{|l|}{ HGR Mwangeji } & HPK Gécamines & \multicolumn{2}{l|}{\begin{tabular}{l} 
Percentage \\
\cline { 2 - 5 }
\end{tabular}} & $\begin{array}{l}\text { prescriptions } \\
\text { containing the class of: }\end{array}$ & $\begin{array}{l}\text { prescriptions containing } \\
\text { the class of: }\end{array}$ & $\begin{array}{l}\text { Percentage } \\
(\%)\end{array}$ \\
\hline Antacids & 146 & 3.4 & 121 & 1.9 \\
\hline Anti-anemics & 50 & 1.4 & 139 & 2.2 \\
\hline Antibiotics & 1125 & 23.5 & 1658 & 26.6 \\
\hline Antidiabetics & 42 & 0.9 & 102 & 1.7 \\
\hline Antifungals & 86 & 1.8 & 53 & 0.8 \\
\hline Antihistamines & 234 & 3.8 & 185 & 3.0 \\
\hline Antihypertensives & 121 & 2.5 & 170 & 2,7 \\
\hline Antimalarials & 620 & 13.0 & 603 & 9,7 \\
\hline Antispasmodics & 156 & 3.3 & 117 & 1,9 \\
\hline Antitussives & 335 & 7.0 & 388 & 6,2 \\
\hline Corticosteroids & 229 & 4.8 & 257 & 4,1 \\
\hline Dewormings & 386 & 8.1 & 546 & 8,8 \\
\hline NSAIDs & 451 & 9.4 & 1061 & 17 \\
\hline Painkillers & 420 & 8.8 & 334 & 5,4 \\
\hline Psychotropics & 30 & 0.7 & 26 & 0,4 \\
\hline Vitamins & 456 & 9.6 & 477 & 7,7 \\
\hline
\end{tabular}

NSAIDs: Non-Steroidal Anti-Inflammatory Drugs 


\subsection{Detected drug interactions}

In all analyzed medical prescriptions ( $n=4759), 5.8 \%$ contained drug interactions. These interactions may be divided into two groups; those that be avoided with precautions for use $(76.7 \%$; $=279)$ and those to be considered during treatment $(23.3 \% ; n=279)$. The following table contains interactions observed in this study.

Table 4 Types of drug interactions encountered in the prescriptions of two hospitals involved in this study.

\begin{tabular}{|c|c|c|}
\hline $\begin{array}{l}\text { Level of attention } \\
\text { required }\end{array}$ & Observed Association & $\begin{array}{l}\text { Identified interaction and its } \\
\text { consequences }\end{array}$ \\
\hline \multirow{3}{*}{$\begin{array}{l}\text { To be considered } \\
\text { during treatment }\end{array}$} & Two $\mathrm{H} 1$ antihistaminic medications & $\begin{array}{l}\text { Potentiation of sedative effects and } \\
\text { impaired alertness }[10,11] .\end{array}$ \\
\hline & NSAIDs and corticosteroid & $\begin{array}{l}\text { Increased risk of ulceration and } \\
\text { gastrointestinal haemorrhage [12]. }\end{array}$ \\
\hline & Captopril and Spironolactone & Induction of hyperkalaemia [13]. \\
\hline \multirow{4}{*}{$\begin{array}{l}\text { Requiring } \\
\text { precautions takes }\end{array}$} & $\begin{array}{l}\text { Captopril, hydrochlorothiazide and } \\
\text { digoxin }\end{array}$ & $\begin{array}{l}\text { May cause hypokalaemia favouring the toxic } \\
\text { effects of digoxin, arrhythmia [14]. }\end{array}$ \\
\hline & Pyrimethamine and trimethoprim & $\begin{array}{l}\text { Induce megaloblastic anaemia due to folic } \\
\text { acid deficiency [15]. }\end{array}$ \\
\hline & Captopril and furosemide & $\begin{array}{l}\text { A risk of abrupt arterial hypotension and/or } \\
\text { acute renal impairment }[13,16] \text {. }\end{array}$ \\
\hline & Furosemide and ibuprofen & $\begin{array}{l}\text { Acute renal impairment by decreasing } \\
\text { glomerular filtration, and reducing the } \\
\text { antihypertensive effect [12]. }\end{array}$ \\
\hline
\end{tabular}

\section{Discussion}

This study was undertaken to identify the degree to which physicians conform to guidelines related to prescription writing during their clinical practice [17]. A total of 4759 outpatient medical prescriptions from HGR-Mwangeji and HPK-Gécamines in Kolwezi, Lualaba province, (DR Congo) were screened for the essential elements of prescriptions according to universal guidelines in this domain. To our best knowledge, this the first such study, in the city of Kolwezi.

The lack of: ( $i$ ) some details on patient's, and/or prescriber's identity, the date of prescription; (ii) the presence of readability of the writings, and/or the drug interactions, as well as the contraindications decrease proportionately the quality of medical prescription [18]. Our results show that the patient's identity was quite good in the prescriptions from HGR-Mwangeji compared to those from HPK-Gécamines (Table 1). In both hospitals, the weight of patient was the least mentioned. These results are similar to those obtained in Lubumbashi by Kaponda et al. [19]. This shows a certain negligence on the part of prescribers who seem to ignore the importance of weight, as a parameter intervening in the dosage adjustment of drugs [20]. In addition, even though the other elements identifying prescribers were generally mentioned in the two hospitals, the professional serial number was poorly written on medical prescriptions. The lack of professional serial numbers of prescribers on their prescriptions represent a danger of falsification endangering the patient's life [21]; knowing that this number constitutes the national identification element for physicians in DR Congo.

In the information to be provided on prescribed drugs, the results show that the treatment duration and the route of administration were reported in less than $70 \%(n=1753)$ at HGR-Mwangeji, while the prescriptions containing dosage, route of administration and duration of treatment for prescribed drugs did not reach $70 \%(\mathrm{n}=3006)$ at HPK-Gécamines. These results show that the low frequency of mention of the routes of administration is because it is assumed that the pharmaceutical form indirectly determines the route of administration of the drug [22]. However, the indication of the route of administration is still important, and the physicians should pay attention to it; because there are pharmaceutical forms that may lead to confusion [23]. For example, there is vaginal tablets whereas tablets are supposed to be taken per os [24]. On the medical prescriptions coming from HPK-Gécamines there was a lot of information missing on the prescribed drugs notably the dosage. The absence of information on the correct dosage of the drug to be used can lead the patient to consume the same medication with an inadequate dosage which can either lead to therapeutic failure or to toxicity [25]. 
More than $20 \%$ of prescriptions from both hospitals contained at least one antibiotic; and by the way antibiotics are the most used drugs at HGR-Mwangeji as well at HPK-Gécamines. There is however the need to know if this strong use of antibiotic is rational when cases of resistance to antibiotics are more and more reported in the region [26]; and the use of antibiotics, should only be used infrequently to avoid the onset of resistance [27]. At HGR-Mwangeji and HPKGécamines hospitals, antimalarials products come second and third respectively among the drugs prescribed, while malaria and infections remain endemic throughout the region and explain the large prescription of antibiotics and antimalaria [28]. It is, however, encouraging to note that few prescriptions contained drug-drug interactions requiring attention. Predominance of generics products in the analyzed medical prescriptions would be explained by their economic accessibility [29]. Finally, it should be mentioned that the quality of medical prescriptions at HGR-Mwangeji and HPK-Gécamines exposes patients to the problem of misuse of drugs which can result in therapeutic failures, toxicity, etc., [30].

\section{Conclusion}

This study aimed at evaluating the quality of medical prescriptions in 2 hospitals in the city of Kolwezi, has highlighted the following major observations: $(i)$ the absence of elements of identity, in particular sex and weight for the patients and, professional serial number and sometimes the signature for the prescribers; (ii) the lack of information on the route of administration and the duration of treatment mainly for certain prescribed drugs; (iii) the occurrence of possible drug interactions in certain patients. The quality of the medical prescriptions at HGR-Mwangeji as at HPKGécamines exposes some patients to a misuse of drugs and to consequences like therapeutic failure and toxicity. The regular prescription of antibiotics under the conditions described in this study may contribute largely to an additional danger that of the development of resistance to antibiotics.

\section{Compliance with ethical standards}

\section{Acknowledgments}

The authors sincerely thank the managers of HGR-Mwangeji and HPK-Gécamines, who have authorized access to the medical prescriptions of their respective structures.

\section{Disclosure of conflict of interest}

The authors declare no competing interests.

\section{References}

[1] Velo GP, Minuz P. Medication errors: prescribing faults and prescription errors. Br J Clin Pharmacol. 2009; 67: 624-8.

[2] Raza UA, Latif S, Naseer A, Saad M, Zeeshan MF, Qazi U. Introducing a structured prescription form improves the quality of handwritten prescriptions in limited resource setting of developing countries. J Eval Clin Pract. 2016; 22: 714-20.

[3] De Vries TPG, Hernning RH, Hogerzeil H V, Fresle DA, Policy M. World Health Organization. Guide to good prescribing: a practical manual / authors: T. P. G. M. de Vries ... [et al.]-with contributions from F. M. Haaijer ; Ruskamp and R. M. van Gilst. Geneva: World Health Organisation. 1994.

[4] Lau DT, Briesacher BA, Touchette DR, Stubbings J, Ng JH. Medicare part D and quality of prescription medication use in older adults. Drugs Aging. 2011; 28: 797-807.

[5] Leão DFL, Moura CS de, Medeiros DS de. Avaliação de interações medicamentosas potenciais em prescrições da atenção primária de Vitória da Conquista (BA), Brasil. Cien Saude Colet. 2014; 19: 311-8.

[6] Fadare J0, Agboola SM, Alabi RA. Quality of prescriptions in a tertiary care hospital in South-West Nigeria. J Appl Pharm Sci. 2013; 3: 81-4.

[7] Sondo B, Ouédraogo V, Ouattara TF, Garane P, Savadogo L, Kouanda S, et al. Etude de la qualité rédactionnelle des ordonnances médicales à la caisse de sécurité sociale de Ouagadougou. Sante Publique (Paris). 2002; 14: 31-6.

[8] World Medical Association. World Medical Association Declaration of Helsinki. JAMA. 2013; 310: $2191-2194$.

[9] EU. General Data Protection Regulation. Off J Eur Union. 2018; 4. 
[10] Bartra J, Valero AL, del Cuvillo A, Dávila I, Jáuregui I, Montoro J, et al. Interactions of the H1 antihistamines. J Investig Allergol Clin Immunol. 2006; 16: 29-36.

[11] Del Cuvillo A, Mullol J, Bartra J, Dávila I, Jáuregui I, Montoro J, et al. Comparative pharmacology of the H1 antihistamines. J Investig Allergol Clin Immunol. 2006; 16: 3-12.

[12] Cooney N, Pollack C, Butkerait P. Adverse drug reactions and drug\&amp;ndash;drug interactions with over-thecounter NSAIDs. Ther Clin Risk Manag. 2015; 11: 1061.

[13] Iskandar H, Hidayat UW, Hersunaryati Y, Syamsundin A. retrospective study on the potential drug interaction betwen angiotensin converting enzyme inhibitor or angiotensin receptor antagonist and other drug in end-stage chronic renal faillure patients. Int Res J Pharm. 2012; 3: 86-9.

[14] Unger T, Kaschina E. Drug Interactions with Angiotensin Receptor Blockers: A Comparison with Other Antihypertensives. Drug Saf .2003; 26: 707-20.

[15] Zimmerman J, Selhub J, Rosenberg IH. Competitive inhibition of folate absorption by dihydrofolate reductase inhibitors, trimethoprim and pyrimethamine. Am J Clin Nutr. 1987; 46: 518-22.

[16] Moreira RIAM, De Bortoli CSH. Prevalence of potential drug interactions in patients in an intensive care unit of a university hospital in Brazil. Clinics. 2011; 66: 9-15.

[17] Calop J, Brudieu É, Allenet B. Méthodologie de validation d’ordonnance. In: Elsevier Masson, editor. Pharm. Clin. thérapeutique. 3ème, Paris: Elsevier. 2008; 31-8.

[18] Holbrook A, Liu JT, Rieder M, Gibson M, Levine M, Foster G, et al. Prescribing competency assessment for Canadian medical students: a pilot evaluation. Can Med Educ J. 2019; 10: e103-110.

[19] Kaponda A, Muya K, Batena B, Kalonji M, Koto KK. Étude de la conformité formelle des prescriptions médicales dans un milieu hospitalier, cas des cliniques universitaires de Lubumbashi. Le Pharm Hosp Clin. 2019; 54: 4955.

[20] Legris ME, Desforges K. Ajustement posologique : pour un choix éclairé de la formule d'estimation de la fonction rénale. Pharmactuel. 2017; 50: 34-44.

[21] Jouanjus E, Guernec G, Lapeyre-Mestre M. Medical prescriptions falsified by the patients: a 12-year national monitoring to assess prescription drug diversion. Fundam Clin Pharmacol. 2018; 32: 306-22.

[22] Alsante KM, Huynh-Ba K, Baertschi SW, Reed RA, Landis MS, Kleinman MH, et al. Recent trends in product development and regulatory issues on impurities in active pharmaceutical ingredient (API) and drug products, part 1: predicting degradation related impurities and impurity considerations for pharmaceutical dosage forms. AAPS PharmSciTech. 2014; 15: 198-212.

[23] Calabrese AD, Erstad BL, Brandl K, Barletta JF, Kane SL, Sherman DS. Medication administration errors in adult patients in the ICU. Intensive Care Med. 2001; 27: 1592-8.

[24] Notelovitz M. Estradiol absorption from vaginal tablets in postmenopausal women. Obstet Gynecol. 2002; 99 : 556-62.

[25] Sjøblom B, Benth JS, Gronberg BH, Baracos VE, Sawyer MB, Flotten O, et al. Drug Dose Per Kilogram Lean Body Mass Predicts Hematologic Toxicity From Carboplatin-Doublet Chemotherapy in Advanced Non-Small-Cell Lung Cancer. Clin Lung Cancer. 2017; 18: e129-36.

[26] Tshibind Y, Mutomb M, Mbaz M, Tshisand K, Kapend M, Tshamba M, et al. Analysis of the In-vitro Resistance developed by Uropathogenic Enterobacteria towards Antibiotics commonly used against the Urinary Infections in the City of Lubumbashi (DRC). J Appl Med Sci. 2014; 3: 23-30.

[27] MacGowan A, Macnaughton E. Antibiotic resistance. Medicine (Baltimore). 2017; 45: 622-8.

[28] Mvumbi DM, Bobanga TL, Melin P, De Mol P, Kayembe J-MN, Situakibanza HN-T, et al. High Prevalence of Plasmodium falciparum Infection in Asymptomatic Individuals from the Democratic Republic of the Congo. Malar Res Treat. 2016; $1-4$.

[29] Adekola TA. Public health-oriented intellectual property and trade policies in Africa and the regional mechanism under trade-related aspects of intellectual property rights amendment. Public Health. 2019; 173: 1-4.

[30] Flacks S. Dangerous drugs, dangerous mothers: Gender, responsibility and the problematisation of parental substance use. Crit Soc Policy. 2019; 39: 477-97. 